\title{
Een voorlopige oplossing Enkele notities bij de Wet van 15 december 1993 (S. 1994, 13)
}

\author{
L.C.M. Meijers ${ }^{* * *}$
}

Zijn woordkeus ten spijt, zal ook de wetgever zich ervan bewust zijn dat een wettelijke regeling niet bij machte is "knelpunten van legislatieve aard" (woorden uit de memorie van toelichting bij wetsontwerp nr. 22909 met wijzigingen "omtrent de terbeschikkingstelling en de observatie") op te lossen ("dienen te worden opgelost", zegt de toelichting). Het is waar dat de wetgever met de Wet van 15 december 1993 (gepubliceerd in Staatsblad 1994, 13 en op 15 januari 1994 in werking getreden) een knoop heeft doorgehakt - nadat de rechter hem, zoals vaker het geval is, was voorgegaan (o.m. Rb. Breda 24 april 1989, Rb. Amsterdam 11 april 1990, ${ }^{1}$ Hoge Raad 29 juni 1993, NJ 1994, 48 (met noot ThWvV) - en een regeling heeft getroffen voor, kort gezegd, de plaatsing in een psychiatrisch ziekenhuis (art. 37 $\mathrm{Sr}$ ) en de terbeschikkingstelling (art. 37a Sr) - en de verlenging ervan (art. 509 o Sv) - van iemand die niet wil meewerken aan de totstandkoming van het advies dat de rechter nodig heeft. De verwachting wordt gewekt dat met deze "zogeheten reparatiewet" ${ }^{2}$ nu ook de kwestie van de "weigerende observandus" geregeld is. Maar bij de gedachte aan een oplossing passen, naast onder meer de beschouwingen, die in de bundel Overheid en patiënt (1993) aan het onderwerp zijn gewijd, nog enige kanttekeningen. De eerste raakt de aard van de rechtsvormende werkzaamheid. De tweede gaat over de observatie als gedragskundige handeling, ook in verband met de "Wet omtrent de overeenkomst inzake geneeskundige behandeling" (WGBO). De derde houdt verband met de ruimte die het verschijnsel van de weigerende observandus aan de gedragskundige en de rechter laat.

${ }^{* * *}$ Advocaat-Generaal bij de Hoge Raad en em. bijzonder hoogleraar Internationaal Strafrecht RU Groningen.

1Vermeld door E. Hofstee in Delikt en Delinkwent (DD) 1991, p. 382.

${ }^{2}$ H.J.C. van Marle, Observatie tegen het licht gehouden, in J.W. Fokkens e.a. red., Overheid en patiënt. Ontwikkelingen in de forensische psychiatrie, Arnhem Gouda Quint 1993, p. 83-93, i.h.b. p. 83. 


\section{De voorlopigheid van een juridische "oplossing"}

Ook voor het recht, zoals dit in de nieuwe regels omtrent de terbeschikkingstelling is geformuleerd, geldt dat het "een discursieve grootheid (is), dit wil zeggen het altijd voorlopige resultaat van een proces van meningsvorming en overtuiging, zowel in abstracto als bij de beslissing in concreto". ${ }^{3}$ Dat heeft in het bijzonder te maken met het feit dat de zwaarte van belangen, die bij de voorbereiding van een wettelijke regeling en van de rechterlijke beslissing in een concreet rechtsgeding worden gewogen, en de verhouding tussen die belangen worden beïnvloed door factoren van, kort gezegd, de maatschappelijke, inclusief politieke, omgeving. Ook de wetgeving en de rechtspraak over de maatregel van de terbeschikkingstelling en, om een schoolvoorbeeld te noemen, de (lange geschiedenis van de) gedwongen opneming van een patiënt in een psychiatrische inrichting maken dit duidelijk. ${ }^{4}$ De slinger gaat op en neer tussen moeilijk met elkaar te verzoenen belangen, die zonder uitzondering van betekenis zijn voor de samenleving, ${ }^{5}$ zoals het belang van een verdachte of veroordeelde bij bescherming van zijn of haar vitale rechten - waaronder het recht om geen medewerking aan de totstandkoming van een gedragskundig advies te geven - en het belang van de samenleving bij beveiliging tegen ingrijpende inbreuken op vitale rechten van anderen. De memorie van toelichting bij wetsontwerp 22909 leest in het arrest van de Hoge Raad van 27 februari 1990 (NJ 1990, 517) de nevenschikking van "het belang van actuele deskundige advisering" en "het belang van een efficiënte rechtspleging" (p. 3). Wat er van deze, nogal instrumenteel geformuleerde, omschrijving zij, wet en rechtspraak kunnen, ook wanneer het over de "weigerende observandus" gaat, slechts een bescheiden pretentie hebben. In die pretentie wordt rekening gehouden met de uitkomst dat, naar de huidige gedragskundige en juridische inzichten van wetgever en rechter, de weigering van een verdachte of veroordeelde om aan een gedragskundig onderzoek mee te doen niet steeds aan een plaatsing in een psychiatrisch ziekenhuis in de weg staat, noch aan een last tot verpleging in

3J.B.M. Vranken, Algemeen Deel van Asser's handleiding tot de beoefening van het Nederlands burgerlijk recht, 1995, nr. 105.

4 Zie het artikel van A.W.M. Mooij in deze bundel.

5In het voorlopig verslag van de vaste Commissie voor Justitie uit de Tweede Kamer wordt, niet nauwkeurig, de term "het publiek belang" gereserveerd voor belangen die met de "veiligheid van de maatschappij" verband houden (kamerstuk 22 909. nr. 5, p. 4). 
een inrichting voor ter beschikking gestelden of aan een beslissing tot verlenging van de terbeschikkingstelling. Het is nuttig hierbij te vermelden dat de afweging zelf en het optreden van verschillen in de uitkomst daarvan niet betekenen dat met grondbeginselen van een samenleving, die op het recht is gebaseerd, - beginselen die met vrijheid, humaniteit en veiligheid te maken hebben - wordt geschipperd. ${ }^{6}$

\section{Observatie van een weigering}

Niemand behoeft zich een medische of gedragskundige verrichting te laten welgevallen. Ook aan (klinische) observatie door een gedragskundige, ${ }^{7}$ als waarop art. 196 Sv ziet, mag en kan $^{8}$ ieder zich onttrekken. Maar een verbod aan wie dan ook om het weigeren en het zoeken van isolement van een ander waar te nemen zou neerkomen op een gebod om ogen en oren dicht te houden. Zo'n gebod kent het recht bij mijn weten niet. Het registreren van iemands weigering ten behoeve van een derde kan onder omstandigheden een inbreuk op de persoonlijke levenssfeer van de weigeraar inhouden. Art. 37 derde lid en art. 37b tweede lid Sr en de artikelen 196 en 509o Sv bieden voor de rechtvaardiging van, onder meer, deze inbreuk de wettelijke basis die door de Nederlandse grondwet en het Europese mensenrechtenverdrag wordt geëist.

De observatie van de (aard en omvang van de) weigering valt niet onder de WGBO. Deze observatie heeft weliswaar (zie de tekst van art. 7:446 tweede lid onder a. BW) "rechtstreeks betrekking op een persoon", maar strekt er niet toe, "hem op zijn gezondheidstoestand te beoordelen". Zij is dus geen verrichting in de zin van art. 7:446 lid 2 BW. ${ }^{9}$

6In deze zin A.C. 't Hart in Mededelingen van de Afdeling Letterkunde van de Koninklijke Nederlandse Akademie van Wetenschappen, 1995, p. 124.

${ }^{7}$ De wetgever gebruikt zowel in art. $37 \mathrm{Sr}$ als in art. 509o Sv het taalkundig en logisch onzuivere woord "gedragsdeskundigen", waar het over gedragskundigen gaat. (In de memorie van toelichting worden op p. 5 beide woorden onmiddellijk na elkaar gebruikt.) De tweede naamval van "dat" slaat op de kundigheid waarover het in de context gaat. Daarom spreken we niet over geneesdeskundigen, opvoeddeskundigen, enz..

8In het P.B.C. zijn geen camera's of microfoons in de cellen aangebracht (Van Marle t.a.p., p. 82).

${ }^{9}$ Met de verrichtingen, waaronder klinische observatie, in het P.B.C. en in tbsinrichtingen ligt dit anders. Ik volsta met verwijzing naar de kritische opmerkin- 


\section{Ruimte voor de gedragskundige en de rechter}

De derde kanttekening heeft te maken met de eisen die de professie van de gedragskundige en van de rechter aan deze beroepsbeoefenaren stelt in de niet zeldzame gevallen ${ }^{10}$ dat zij met een weigerende observandus te maken hebben. Volledigheidshalve: weigering is, ook in dit verband, de beslissing van iemand die de alternatieven in redelijke mate kan overzien en die gebruik maakt van zijn recht zich niet te laten onderzoeken of te observeren. De patiënt-verdachte (of -veroordeelde) wiens verzet naar het oordeel van de gedragskundige niet op een bewuste keuze berust, omdat het een gevolg is van een stoornis in de oordeelsvorming, wordt niet als weigerende observandus beschouwd. ${ }^{11}$

Het is op voorhand al ondenkbaar dat toepassing van deze of een andere wettelijke regeling van de weigerende observandus voor elk geval tot dezelfde uitkomst leidt. Er doen zich naast subjectieve verschillen tussen de actoren wisselende zakelijke factoren voor: de delicten die tot plaatsing in het PBC of tot oplegging van de maatregel van tbs hebben geleid verschillen in ernst; de bedreiging van de veiligheid van de samenleving is van ongelijke zwaarte; er zijn gradaties in weigerend gedrag en dus in de mogelijkheden van observatie en rapportering ervan.

Voor de gedragskundige betekent de regeling van art. $37 \mathrm{Sr}$ (c.a.) dat een weigering niet mag worden overruled; de mogelijkheden van de gedragskundige reiken niet verder dan de observandus hem toestaat. Art. 37 lid $3 \mathrm{Sr}$ legt de gedragskundige een inspanningsverplichting op. Dit karakter van de verplichting en het, daaraan ten grondslag liggende, weigeringsrecht van de observandus spreken uit het dubbele voorbehoud in de wettelijke bepalingen $^{12}$ : voor zover mogelijk maken de gedragskundigen gezamenlijk dan wel

gen van J.H. Hubben, Enkele problemen uit de praktijk, in Tussen vrijheid en onvrijheid, Arnhem Gouda Quint, 1988, p. 65-73 i.h.b. 69-70, en Overheid en patiënt vanuit juridisch perspectief; enkele recente ontwikkelingen, in Overheid en patient, p. 21-29 i.h.b. p. 24-25, en B. Sluyters, De Geneeskundige behandelingsovereenkomst, in WPNR nr. 5982, p. 763.

${ }^{10}$ In het Pieter Baan Centrum jaarlijks meer dan 10\% van de circa 190 opnemingen (Van Marle t.a.p., p. 82).

11Vgl. memorie van toelichting, p. 11, en F.A.M. Bakker, Requiem voor de weigerende observandus? in Overheid en patiënt, p. 93-103 i.h.b. p. 96.

12Dat het voorbehoud zich de ene keer tot de gedragskundige, de tweede keer tot de 
ieder van hen afzonderlijk over de reden van de weigering rapport op, en: zoveel mogelijk stellen de gedragskundigen een nader advies of rapport op over de wenselijkheid of noodzakelijkheid van plaatsing in een psychiatrisch ziekenhuis of van de maatregel van terbeschikkingstelling (art. 37 lid 3 en art. $37 \mathrm{~b}$ lid $2 \mathrm{Sr}$ ). Hetzelfde geldt ten aanzien van de verlenging (art. 509o lid 4). De gedragskundige zal bij de opstelling van zijn "nader advies of rapport" ook rapporten en adviezen betrekken die eerder over de observandus zijn uitgebracht. ${ }^{13}$

Kortom: de gedragskundige heeft naar mijn mening ten aanzien van een weigerende observandus voldoende ruimte om overeenkomstig de eisen van zijn professionele standaard naar bevind van zaken te handelen.

De rechter is ten slotte de door de wet aangewezen autoriteit om over iemands plaatsing in een psychiatrisch ziekenhuis, over de terbeschikkingstelling of de verlenging ervan te beslissen. De rechterlijke beslissing loopt via het beproefde procédé van feitenvaststelling en waardering van de belangen, die in het geding zijn, naar een uitkomst die naar het oordeel van de rechter voor het concrete geval redelijk is. De beslissing mag alleen gebaseerd zijn op de gegevens die de raadsman van de geobserveerde persoon, het openbaar ministerie en, via dezen, de gedragskundigen op tafel hebben gelegd. Op de noodzaak van juist deze juridische vormgeving heeft vooral C. Kelk gewezen: "De belangrijkste conditie voor een juridisch én medisch verantwoorde beslissing lijkt mij gegeven in een contradictoire procedure, dat wil zeggen een procedure op tegenspraak". ${ }^{14}$ Het debat op de terechtzitting zal, als het over plaatsing en (verlenging van) ter beschikking stelling gaat, steeds betrekking hebben op de zwaarte van het delict en het gevaar dat de verdachte (of veroordeelde) voor de gemeenschap vormt, op de, onvermijdelijk veranderende, inhoud van deze beide factoren en op hun onderlinge verhouding. Ten aanzien van de weigerende observandus komen daar als voorwerp van debat en afweging bij: de aard en de omvang van zijn weigering en de dreiging van een lange gevangenisstraf als bizarre maar soms onvermijdelijke consequentie van een weigerende houding.

rechter en, in art. 509o lid $4 \mathrm{~Sv}$, tot het openbaar ministerie richt, is in dit verband niet van belang.

13Zie o.a. Van Marle t.a.p., p. 85.

${ }^{14} \mathrm{C}$. Kelk, Recht en psychiatrische behandeling in de strafrechtspleging, een nog te weinig uitgewogen verhouding, in Strafrecht in balans (Geurtsbundel, 1983), p. 103. 


\begin{abstract}
Afsluitende opmerking
In verband met de wettelijke regeling van de terbeschikkingstelling valt, evenals bij de gedwongen plaatsing van een patiënt in een psychiatrisch ziekenhuis, soms, en niet zonder grond, het woord juridisering. J. Legemaate omschrijft dit begrip als een toenemende invloed van juridische interventies (bijvoorbeeld wetgeving en jurisprudentie) op sociale relaties die bestaan binnen de gezondheidszorg. ${ }^{15}$ Het gevaar van een te vérgaande vormgeving door het recht, met ongunstige gevolgen niet alleen voor de gezondheidszorg, is zeker niet denkbeeldig in een tijd met een eenzijdige belangstelling voor de effecten van instrumentele sturing. Bovenstaande notities dragen misschien ertoe bij de vrees wat te temperen: ook de wetgever, die het knelpunt van de weigerende observandus op wil lossen, is niet bij machte gedragskundigen en rechters de ruimte te ontnemen die hun professie eist.
\end{abstract}

15J. Legemaate, De wet bijzondere opnemingen in psychiatrische ziekenhuizen: rechtsbescherming of ongewenste juridisering, in Ned. Tijdschr. Geneeskunde 1994, p. 847. 